\title{
A case-control study on the association of idiopathic recurrent pregnancy loss with autoantibodies against $\beta 2$-glycoprotein I and annexin $\mathrm{V}$
}

\author{
Walid Zammiti, Nabil Mtiraoui, Choumous Kallel, Eric Mercier ${ }^{1}$, Wassim Y Almawi ${ }^{2}$ and \\ Touhami Mahjoub \\ Laboratory of Hematology, Faculty of Pharmacy, University of Monastir, Tunisia, ${ }^{1}$ University of Montpellier, \\ Montpellier, France, ${ }^{2}$ Department of Medical Biochemistry, College of Medicine and Medical Sciences, \\ Arabian Gulf University, P O Box 22979, Manama, Bahrain
}

Correspondence should be addressed to WY Almawi; Email: wyalmawi@yahoo.co.uk

\begin{abstract}
Whereas antiphospholipid antibodies (aPL) are associated with thrombotic events and recurrent spontaneous abortion (RSA), the contribution of anti- $\beta 2$ glycoprotein 1 ( $\beta 2 G P 1)$ and anti-annexin V antibodies as risk factors for RSA remain poorly under-

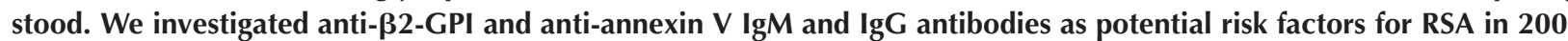
women with more than three consecutive idiopathic RSA, and 200 age-matched, healthy, parous women. Pearson's chi squared test analysis showed that while anti- $\beta 2-G P I \operatorname{IgG}(P=0.416)$ and $\operatorname{IgM}(P=0.72)$ were comparable between patients and controls, elevated anti-annexin V IgG $(P=0.006)$, but not $\operatorname{IgM}(P=0.084)$, was more pronounced in patients. Higher frequencies of elevated IgG-only $(P=\mathbf{0 . 0 0 5})$, but not IgM-only $(P=1.000 ; O R=6.66)$, anti-annexin $V$ antibodies were noted among patients. Multinomial regression analysis showed that body-mass index (overweight and obesity; $P=0.008$ ), education status $(P<0.001)$ and anti- $\beta 2-G P I \operatorname{IgM}(P=0.033)$, but not IgG $(P=0.723)$, were associated with early abortion, while

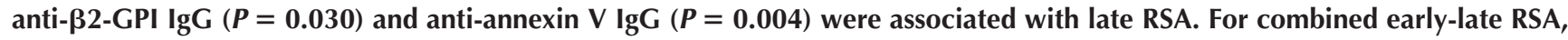
the only variable selected was education status $(P<\mathbf{0 . 0 0 1})$, and neither anti-annexin $V$ nor anti- $\beta 2-G P I$ IgM and IgG was associated with early-late RSA. Accordingly, anti-annexin $\mathrm{V}$ and anti-ß2-GPI should be regarded as independent risk markers of RSA.

Reproduction (2006) 131 817-822
\end{abstract}

\section{Introduction}

Pregnancy loss after implantation is frequent (Wilcox et al. 1988, Chaouat et al. 1995), and idiopathic recurrent spontaneous abortion (RSA) is often seen in otherwise healthy women (Mahjoub et al. 2005, Quenby et al. 2005). While several mechanisms have been proposed for early RSA (Huang et al. 2005), the exact causes of late miscarriage remain poorly understood. Inherited thrombophilia, including point mutations in factor $\mathrm{V}$ (Leiden) and prothrombin (G20210A) genes (Mahjoub et al. 2005), and antiphospholipid (aPL) antibodies, including anticardiolipin (aCL) antibodies and lupus anticoagulant (LA) (Mtiraoui et al. 2005), constitute significant risk factors for late RSA (Gris et al. 1999, Norwitz et al. 2001), since women who are carriers of prothrombotic gene polymorphisms or aPL are predisposed to pregnancy failure due to placental thrombosis (Gris et al. 1999, Martinelli et al. 2002).
Insofar as they recognize many phospholipids, phospholipid-binding proteins, or both, aPL antibodies have been associated with a hypercoagulable state - antiphospholipid syndrome (APS) - which arises from platelet activation, impairment of the endothelial system and facilitation of blood coagulation (Mercanoglu et al. 2004), and have been implicated in pregnancy complications (Gris et al. 2003, Levine et al. 2002, Rand et al. 2005). The precise mechanism of aPL in precipitating fetal loss is unclear, and may include precipitation of a prothrombotic state in the uteroplacental vasculature (Matsubayashi et al. 2001). $\beta 2$-Glycoprotein I ( $\beta 2-G P I)$, a single-chain $50 \mathrm{kDa}$ glycoprotein and a target of aPL (Galli et al. 1990), was found to be involved in RSA, as its reduced expression was reported in women with APS (Miyakis et al. 2004). Antibodies to $\beta 2$-GPI (anti- $\beta 2-\mathrm{GPI}$ ) were described as prothrombotic in individuals with APS (Falcon et al. 1997), and were suggested to play a role in RSA, since they inhibit trophoblast proliferation (Norwitz et al. 2001), and 
enhance uteroplacental thrombosis and abnormal placentation (Gris et al. 2003).

In addition to $\beta 2-\mathrm{GPI}$, annexin $\mathrm{V}$ is a potent anticoagulant that regulates exocytosis and syncytiotrophoblast membrane fusion (Arai et al. 2003), and has been implicated in RSA, as shown by findings that anti-annexin $\mathrm{V}$ antibodies induce thrombosis in human umbilical vein endothelial cells (HUVEC) (Arnold et al. 2001), and that their concentrations are reduced in isolated placenta from women with aPL-associated RSA (Gris et al. 1999, Matsubayashi et al. 2001). Antibodies against annexin V may interfere with syncytiotrophoblast function (Rand et al. 1994, 2005), resulting in altered expression of anionic lipids on the plasma membrane, and induction of apoptosis in HUVEC (Ailus et al. 1996). Others argue against involvement of anti-annexin V with RSA, since comparable prevalence rates of $\operatorname{IgG}(25 \%$ vs $23 \%)$ and $\operatorname{IgM}(27 \%$ vs $28 \%$ ) anti-annexin $V$ were seen in RSA vs control women respectively (Bizzaro et al. 2005).

We previously reported on the association of aCL antibodies and LA with idiopathic RSA, where elevated aCL antibody-only, positive LA only, or combined elevated aCL-positive LA were consistently higher in RSA patients (Mtiraoui et al. 2005). Since the exact role and clinical significance of anti- $\beta 2-\mathrm{GPI}$ and anti-annexin $\mathrm{V} \operatorname{lgG}$ and IgM antibodies as risk factors for RSA are unclear, this study aimed to determine the prevalence of anti-annexin $V$ and anti- $\beta 2-G P I \operatorname{IgG}$ and IgM antibodies in women with idiopathic RSA, and to evaluate their contribution with other confounding variables in RSA.

\section{Subjects and Methods}

\section{Study subjects}

From 2002 to 2004, 200 women with three or more unexplained consecutive pregnancy losses 5-30 weeks post- gestation (mean age $28.6 \pm 5.6$ years), and attending the hospital maternity service of Sousse (Tunisia), were recruited (Table 1). Pregnancy losses were classified as early (5-10 weeks) and late (11-30 weeks). Exclusion criteria included induced abortions, infections, systemic disease, uterine structural abnormalities, and personal or family history of thrombosis. As control, 200 age-matched, healthy women with uncomplicated pregnancies (mean $28.2 \pm 5.5$ years) were recruited (Table 1). Patients and controls were asked to complete a questionnaire detailing demographic details, number and outcome of pregnancies, and RSA risk factors, and to sign an informed, consent form. The study was conducted after all institutional ethics requirements were met. Blood samples were obtained from study participants 8-12 weeks after the last pregnancy.

\section{Antibody measurements}

Serum anti- $\beta 2$-GPI IgG and IgM levels were measured by quantitative ELISA, using the Zymutest kit according to the manufacturer's instructions (Hyphen Biomed, Neuville-SurOise, France). Results of $<20 \mathrm{U} / \mathrm{ml}$ were interpreted as negative, while specimens with values of $\geq 20 \mathrm{U} / \mathrm{ml}$ were considered positive. Serum samples were also tested for anti-annexin $\mathrm{V} \operatorname{IgG}$ and IgM by quantitative ELISA, using the Zymutest kit, according to manufacturer's instructions (Hyphen Biomed). Results of $<20 \mathrm{U} / \mathrm{ml}$ were interpreted as negative and results of $\geq 20 \mathrm{U} / \mathrm{ml}$ as positive.

\section{Statistical analysis}

First, we examined means and standard deviation of all biomarkers in case and control patients. Statistical analysis was performed on SPSS v. 11.5 statistics software (SPSS, Chicago, IL, USA). Data were expressed as percentages of the mean. The Mann-Whitney nonparametric U-test, regression multinomial logistic and Pearson's chi-square test were used to assess intergroup significance. In

Table 1 Clinical characteristics of patients and controls.

\begin{tabular}{|c|c|c|c|c|c|}
\hline & Patients $^{1}$ & Controls $^{1}$ & $P$ & OR & $95 \% \mathrm{Cl}$ \\
\hline Age & $28.68 \pm 5.61$ & $28.24 \pm 5.51$ & $0.434^{2}$ & & \\
\hline Regional & 49:50:41:60 & $42: 43: 43: 72$ & $0.531^{3}$ & & \\
\hline Smokers & 9/191 & 9/191 & $1.000^{3}$ & 1.000 & $0.389-2.574$ \\
\hline Education & & & $<0.001^{3}$ & & \\
\hline Intermediate & 41 & 69 & & & \\
\hline Secondary & 81 & 92 & & & \\
\hline University & 78 & 39 & & & \\
\hline Alcohol & 5 & 5 & $1.000^{3}$ & 1.000 & $0.285-3.509$ \\
\hline $\mathrm{BMI}^{4}$ & $25.78 \pm 4.01$ & $24.62 \pm 3.75$ & $0.360^{2}$ & 1.159 & $0.395-1.923$ \\
\hline Oral contraceptives & 51 & 46 & $0.641^{3}$ & 1.146 & $0.725-1.811$ \\
\hline \multicolumn{6}{|l|}{ Pregnancy outcomes } \\
\hline Live & $0.51 \pm 0.72$ & $3.81 \pm 1.40$ & $<0.001^{2}$ & 3.300 & $3.081-3.519$ \\
\hline Early loss & $2.29 \pm 1.30$ & $0.02 \pm 0.14$ & $<0.001^{2}$ & 2.270 & $2.088-2.452$ \\
\hline Late loss & $1.34 \pm 1.30$ & $0.04 \pm 0.184$ & $<0.001^{2}$ & 1.305 & $1.122-1.488$ \\
\hline
\end{tabular}

${ }^{1}$ A total of 200 patient and 200 controls were included.

${ }^{2}$ Fisher's exact test.

${ }^{3}$ Pearson's chi-square test.

${ }^{4}$ Body-mass index, weight $(\mathrm{kg}) /(\text { height }(\mathrm{m}))^{2}$. 
addition, the odds ratios (OR) and 95\% confidence intervals $(\mathrm{Cl})$ were calculated. Statistical significance was set at $P<0.05$.

\section{Results}

\section{Patients and controls}

The characteristics of patients and controls are summarized in Table 1. Both patients and controls had similar age $(P=0.434)$ and body-mass index (BMI; $P=0.360)$, and were from different parts of Tunisia $(P=0.531)$. While there was no significant difference between patients and controls in terms of alcohol consumption $(P=1.000)$ or smoking $(P=1.000)$, differences in terms of education background were noted among study participants $(P<0.001)$, exemplified by the higher proportion of patients having a university-level education, while controls generally had an intermediate level education.

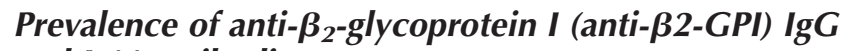 and IgM antibodies}

The status of anti- $\beta 2-G P I \lg G$ and $\lg M$, and that of antiannexin $\mathrm{V} \operatorname{IgM}$ and IgG antibodies were assessed. Anti32-GPI IgG and IgM, and anti-annexin $\mathrm{V} \operatorname{Ig} M$ and $\operatorname{Ig} G$ were categorized as normal or elevated according to a cutoff value of $20 \mathrm{U} / \mathrm{ml}$. Anti- $\beta 2-\mathrm{GPI} \operatorname{lgG}(P=0.416)$ and $\operatorname{lgM}(P=0.72)$ were comparable between patients and controls (Table 2). In contrast, elevated anti-annexin V IgG $(P=0.006)$, but not IgM $(P=0.084)$, was more pronounced in patients than control parous women (Table 2).

\section{Analysis of anti-annexin $V$ antibodies}

In view of the association of anti-annexin $\mathrm{V}$, but not anti$\beta 2-G P I$ antibodies with RSA, we tested the anti-annexin V IgM and IgG status (normal, elevated) in patients and controls. Higher frequencies of elevated IgG-only $(P=0.005)$, but not IgM-only $(P=1.000)$, were noted among patients (Table 3). Only one patient presented with elevated IgM-elevated IgG.

\section{Risk factors for pregnancy loss}

Predictors of early, late and early-late abortions were determined by performing three logistic regression analysis models with the dependent variable being early, late, and early-late RSA, and the independent potentially confounding variables being age, $\mathrm{BMI}$, use of oral contraceptives, education, anti-annexin $\mathrm{V} \operatorname{Ig} M$ and $\operatorname{IgG}$, and anti- $\beta 2$-GPI IgM and IgG (Table 4). The only variables that were selected by this technique for the first outcome (early RSA) were $\mathrm{BMI}$ of $>25(P=0.008)$, education status $(P<0.001)$ and anti- $\beta 2-G P I \operatorname{IgM}(P=0.033)$ (Table 4$)$. For the second outcome (late RSA), it was anti- $\beta 2$-GPI IgG $(P=0.030)$ and anti-annexin $\mathrm{V} \operatorname{IgG}(P=0.004)$. For the third outcome (early-late), the only variable selected was education status $(P<0.001)$. Adjusting for the variables

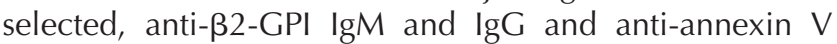
IgM and IgG were not associated with combined earlylate RSA (Table 4).

\section{Discussion}

Autoimmune factors involving production of antibodies targeting phospholipids (cardiolipin and phosphatidylserine) or phospholipid-binding proteins $\left(\beta_{2} \mathrm{GPI}\right.$ and annexin $\mathrm{V})$ were previously described as risk factors for RSA (Martinelli et al. 2002, Gris et al. 2003, Rand et al. 2005). Unlike the well-documented involvement of $\mathrm{aCL}$ and $\mathrm{LA}$, the role of anti-annexin $\mathrm{V}$ and anti- $\beta_{2}$-GPI antibodies in idiopathic RSA has yet to be established, although it is presumed that it involves precipitation of a prothrombotic state that favors altered placentation, poor fetal circulation and possibly induction of apoptosis (Arai et al. 2003, Rand et al. 2005).

Results from this study demonstrated that anti-annexin $V$, but not anti- $\beta_{2}-\mathrm{GPI}$, antibodies were elevated in women with idiopathic RSA. Added to our previous finding on association of aCL and LA with RSA (Mtiraoui et al. 2005), these results indicate that the presence of these autoantibodies is closely related to RSA, via a mechanism which requires participation of immune and nonimmune factors in precipitating a prothrombotic state that favors

Table 2 Prevalence of anti- $\beta_{2}-\mathrm{GPI}$ and anti-annexin V IgG and $\lg M$ antibodies.

\begin{tabular}{|c|c|c|c|c|c|c|}
\hline Antibody & Status & Patients ${ }^{1}$ & Controls $^{1}$ & $\boldsymbol{P}$ & OR & $95 \% \mathrm{Cl}$ \\
\hline Anti- $\beta_{2}$-GPI IgG ${ }^{2}$ & $\begin{array}{l}\text { Normal } \\
\text { Elevated }\end{array}$ & $\begin{array}{r}191(49.5 \%) \\
9(64.3 \%)\end{array}$ & $\begin{array}{r}195(50.5 \%) \\
5(35.7 \%)\end{array}$ & $0.416^{3}$ & 1.84 & $0.61-5.58$ \\
\hline Anti- $\beta_{2}-G P I$ IgM ${ }^{2}$ & $\begin{array}{l}\text { Normal } \\
\text { Elevated }\end{array}$ & $\begin{array}{r}195(49.7 \%) \\
5(62.5 \%)\end{array}$ & $\begin{array}{r}197(50.3 \%) \\
3(37.5 \%)\end{array}$ & $0.72^{4}$ & 1.68 & $0.397-7.14$ \\
\hline Anti-annexin $\mathrm{V} \lg \mathrm{G}^{2}$ & $\begin{array}{l}\text { Normal } \\
\text { Elevated }\end{array}$ & $\begin{array}{r}187(48.6 \%) \\
13(86.7 \%)\end{array}$ & $\begin{array}{r}198(51.4 \%) \\
2(13.3 \%)\end{array}$ & $0.006^{4}$ & 6.88 & $1.53-30.91$ \\
\hline Anti-annexin $\mathrm{V} \operatorname{Ig}^{2}{ }^{2}$ & $\begin{array}{l}\text { Normal } \\
\text { Elevated }\end{array}$ & $\begin{array}{r}184(48.8 \%) \\
16(69.6 \%)\end{array}$ & $\begin{array}{r}193(51.2 \%) \\
7(30.4 \%)\end{array}$ & $0.084^{3}$ & 2.4 & $0.96-5.96$ \\
\hline
\end{tabular}

\footnotetext{
${ }^{1}$ Study comprised 200 patients and 200 controls.

${ }^{2}$ Determined according to normal $<12.5 \mathrm{UA} / \mathrm{ml}$; elevated $>12.5 \mathrm{UA} / \mathrm{ml}$.

${ }^{3}$ Pearson's Chi Squared test.

${ }^{4}$ Fisher's exact test.
} 
Table 3 Isotype distribution of anti-annexin $\vee$ antibodies.

\begin{tabular}{llccccc}
\hline IgM state IgG state & Patients & Controls & $\boldsymbol{P}^{\mathbf{2}}$ & OR & $\mathbf{9 5 \%} \mathbf{~ C I}$ \\
\hline Normal & Normal & $172(93.5)^{1}$ & $191(99.0)$ & 0.005 & 6.66 & $1.47-30.19$ \\
& Elevated & $12(6.5)$ & $2(1.0)$ & & & \\
Elevated & Normal & $15(93.8)$ & $7(100.0)$ & 1.000 & 0.68 & $0.51-0.91$ \\
& Elevated & $1(6.3)$ & $0(0.0)$ & & & \\
\hline
\end{tabular}

${ }^{1}$ Percentage of total within IgM state subcategory.

${ }^{2}$ Chi-square test.

fetal loss. Multivariate regression analysis demonstrated that anti- $\beta_{2}$-GPI IgM was associated with early RSA, while anti-annexin V IgG was a significant risk factor for (exclusively) late RSA. Neither anti- $\beta_{2}-\mathrm{GPI}$ nor annexin $\mathrm{V}$ IgG or IgM was associated with combined early-late RSA. Interestingly, university education was associated with early and early-late RSA. While the cause of this remains speculative, it is possible that sociocultural habits (Tan et al. 1995), together with career-related factors (Bocciolone et al. 1989, Tan et al. 1995), may have contributed to RSA in university-educated women, the majority of whom are working women.

Results on the role of anti- $\beta_{2}$-GPI in RSA are controversial, and some reports described an association of anti$\beta_{2}$-GPI IgG with RSA (Lee et al. 1999, Gris et al. 2000), and others implicated IgM (Foratseiro et al. 1997), but not IgG (Lynch et al. 1999, Arnold et al. 2001) anti- $\beta_{2}-G P I$, as potential risk factor for idiopathic RSA, as also shown here. In our hands, the presence of anti- $\beta_{2}-\mathrm{GPI}$ IgM was associated with (exclusively) early RSA, while IgG was associated with (exclusively) late RSA, in apparent agreement with previous studies which also found no significant association of anti- $\beta_{2}$-GPI antibodies in women with three or more consecutive pregnancy losses (Lynch et al. 1999, Arnold et al. 2001), and in antiphospholipid-positive patients with obstetric complications (two or more spontaneous fetal losses) (Foratseiro et al. 1997). This may be explained by differences in assay sensitivity, and the low number of patients (21-44) included in some studies
(Ailus et al. 1996, Foratseiro et al. 1997). Insofar as aCL antibodies target plasma proteins bound to anionic phospholipids, including $\beta_{2}$-GPI (Marai et al. 2005), it was suggested that the association of anti- $\beta_{2}$-GPI with RSA was dependent on aCL antibody status, since anti- $\beta_{2}-\mathrm{GPI}$ antibody was elevated in aCL-negative patients (Lee et al. 1999). This does not appear to be the case here, since comparable prevalence rates of anti- $\beta_{2}$-GPI were seen in patients and controls, irrespective of $\mathrm{aCL}$ isotype $(P=0.569)$ or status $(P=0.495)$.

In accordance with previous findings (Gris et al. 2000, 2003, Matsubayashi et al. 2001), anti-annexin V antibodies were significantly higher in RSA patients than in fertile women. Logistic regression analysis confirmed the association of anti-annexin V IgG in late RSA, which was reminiscent of the findings of the Nimes group that anti-annexin $\mathrm{V}$ IgG is an independent risk factor for unexplained RSA (Gris et al. 2000, 2003), and in apparent disagreement with other reports, which disputed such an association (Siaka et al. 1999, Arnold et al. 2001, Arai et al. 2003, Bizzaro et al. 2005). However, the small sample size (Siaka et al. 1999, Arnold et al. 2001), coupled with poor assay sensitivity (Siaka et al. 1999), and ethnic origin (Arai et al. 2003, Bizzaro et al. 2005) employed in the latter studies warrants scrutiny in evaluating their conclusion.

While RSA may be partly explained by placental thrombosis precipitated by endothelial cell activation and annexin $\mathrm{V}$ displacement, this does not account for all miscarriages, thus pointing to an antibody-directed mechanism. Accordingly, the presence of antibodies that bind trophoblast-associated $\beta_{2}$-GPI may interfere with trophoblast cell maturation, resulting in defective placentation. In addition, as annexin $\mathrm{V}$ acts as an inhibitor of lipiddependent blood coagulation, antibodies against it may serve a procoagulant function. This was supported by the findings that administration of annexin $\mathrm{V}$ inhibited thrombus formation (Romisch et al. 1991) and fibrin accretion (Van Ryn-McKenna et al. 1993), and administration of anti-annexin $\mathrm{V}$ induced placental thrombosis, necrosis

Table 4 Regression analysis.

\begin{tabular}{lccc}
\hline & & \multicolumn{2}{c}{ Stage of pregnancy loss } \\
\cline { 2 - 4 } Variable & Early & Late & Early + late \\
\hline Age & $1.30(0.67-2.51)^{1}$ & $1.64(0.87-3.11)$ & $0.96(0.64-1.42)$ \\
BMI $^{2}$ & $0.46(0.26-0.82)^{*}$ & $0.98(0.56-1.70)$ & $0.73(0.51-1.03)$ \\
Oral contraceptives $_{\text {Education }}^{3}$ & $1.77(0.58-5.36)$ & $0.47(0.22-1.01)$ & $0.91(0.52-1.60)$ \\
Anti-annexin V & $0.33(0.18-0.61)^{*}$ & $0.63(0.39-1.02)$ & $0.52(0.38-0.73)^{*}$ \\
$\quad$ IgG & $3.94(0.39-39.94)$ & $17.47(2.43-125.49)^{*}$ & $5.02(0.98-25.68)$ \\
IgM & $2.03(0.39-10.68)$ & $2.10(0.46-9.63)$ & $1.90(0.66-5.43)$ \\
Anti- $\beta_{2}$ GPI & & & \\
IgG & $1.51(0.16-14.58)$ & $4.90(1.17-20.54)^{*}$ & $1.06(0.26-4.40)$ \\
IgM & $9.00(1.20-67.72)^{*}$ & $2.22(0.21-24.00)$ & $1.40(0.21-9.30)$
\end{tabular}

\footnotetext{
${ }^{1} \mathrm{OR}(95 \% \mathrm{Cl})$.

${ }^{2}$ Reference being normal BMI (20-25).

${ }^{3}$ Reference being university education.

$* P<0.05$ vs controls.
} 
and fetal loss (Wang et al. 1999). Mechanistically, it was hypothesized that anti-annexin $\mathrm{V}$ antibodies can disrupt or compromise the antithrombotic shield, thereby contributing to reproductive failure. Furthermore, by inducing trophoblast apoptosis and significantly reducing trophoblast gonadotropin secretion, anti-annexin $\mathrm{V}$ antibody was found to induce defective placentation (Di Simone et al. 2001).

As with similar studies, a limitation of our study is that anti-annexin $\mathrm{V}$ and anti- $\beta 2 \mathrm{GPI}$ antibodies were measured in the patients after event establishment (pregnancy failure), thereby raising the possibility that these antibodies were the consequence, and not necessarily the cause of RSA, as was also suggested elsewhere (Gris et al. 2003). This can be resolved only by a prospective study that monitors changes in pregnancy outcomes in antibodypositive versus antibody-negative patients.

In conclusion, our study proposes a role for anti- $\beta 2 \mathrm{GPI}$ $\lg M$ (but not $\lg G$ ) and anti-annexin $\mathrm{V} \lg \mathrm{G}$ antibodies in mediating exclusively early and late RSA respectively. This may serve as a diagnostic tool as part of the routine workup for women with idiopathic RSA, and also has therapeutic implications, evidenced by the utility of combining intravenous immunoglobulin in the standard therapy regimen, which allegedly resulted in excellent fetal and maternal outcome (Branch et al. 2000), in particular in cases of APS (Diejomaoh et al. 2002). However, the definitive utility of this treatment modality awaits the outcome of international randomized trials, which are currently in progress.

\section{Acknowledgements}

The authors declare that there is no conflict of interest that would prejudice the impartiality of this scientific work.

\section{References}

Ailus K, Tulppala M, Palosuo T, Ylikorkala O \& Vaarala O 1996 Antibodies to beta 2-glycoprotein I and prothrombin in habitual abortion. Fertility and Sterility 66 937-941.

Arai T, Matsubayashi H, Sugi T, Kondo A, Shida M, Suzuki T, Izumi SI, McIntyre JA \& Makino T 2003 Anti-annexin A5 antibodies in reproductive failures in relation to antiphospholipid antibodies and phosphatidylserine. American Journal of Reproduction and Immunology 50 202-208.

Arnold J, Holmes Z, Pickering W, Farmer C, Regan L \& Cohen H 2001 Anti-beta 2 glycoprotein 1 and anti-annexin $\mathrm{V}$ antibodies in women with recurrent miscarriage. British Journal of Haematology $113911-914$.

Bizzaro N, Antico A, Musso M, Platzgummer S, Camogliano L, Tozzoli R \& Villalta D 2005 A prospective study of 1038 pregnancies on the predictive value of anti-annexin $\mathrm{V}$ antibodies for fetal loss. Annals of the New York Academy of Sciences $\mathbf{1 0 5 0}$ 348-356.

Bocciolone L, Parazzini F, Fedele L, Acaia B \& Candiani GB 1989 Epidemiology of spontaneous abortion: a review of the literature. Annali di ostetricia, ginecologia, medicina perinatale $\mathbf{1 1 0}$ 323-334.

Branch DW, Peaceman AM, Druzin M, Silver RK, El-Sayed Y, Silver RM, Esplin MS, Spinnato J \& Harger J 2000 A multicenter, placebo-controlled pilot study of intravenous immune globulin treatment of antiphospholipid syndrome during pregnancy. The Pregnancy Loss Study Group. American Journal of Obstetrics and Gynecology 182 122-127.

Chaouat G, Menu E, Delage G, Moreau JF, Khrishnan L, Hui L, Meliani AA, Martal J, Raghupathy R, Lelaidier C et al. 1995 Immuno-endocrine interactions in early pregnancy. Human Reproduction 10 (Suppl 2) 55-59.

Di Simone N, Castellani R, Caliandro D \& Caruso A 2001 Monoclonal anti-annexin $\mathrm{V}$ antibody inhibits trophoblast gonadotropin secretion and induces syncytiotrophoblast apoptosis. Biology of Reproduction 65 1766-1770.

Diejomaoh MF, Al-Azemi MM, Bandar A, Egbase PE, Jirous J, Al-Othman S, Bukhadour N \& Al-Sweih N 2002 A favorable outcome of pregnancies in women with primary and secondary recurrent pregnancy loss associated with antiphospholipid syndrome. Archives in Gynecology and Obstetrics 266 61-66.

Falcon CR, Martinuzzo ME, Forastiero RR, Cerrato GS \& Carreras LO 1997 Pregnancy loss and autoantibodies against phospholipidbinding proteins. Obstetrics and Gynecology 89 975-980.

Forastiero RR, Martinuzzo ME, Cerrato GS, Kordich LC \& Carreras LO 1997 Relationship of anti-beta2-glycoprotein I and anti-prothrombin antibodies to thrombosis and pregnancy loss in patients with antiphospholipid antibodies. Thrombosis and Haemostasis 78 1008-1014.

Galli M, Comfurius P, Maassen C, Hemker HC, de Baets MH, van Breda-Vriesman PJ, Barbui T, Zwaal RF \& Bevers EM 1990 Anticardiolipin antibodies (ACA) directed not to cardiolipin but to a plasma protein cofactor. Lancet 335 1544-1547.

Gris JC, Quere I, Monpeyroux F, Mercier E, Ripart-Neveu S, Tailland ML, Hoffet M, Berlan J, Daures JP \& Mares P 1999 Casecontrol study of the frequency of thrombophilic disorders in couples with late foetal loss and no thrombotic antecedent - the Nimes Obstetricians and Haematologists Study 5 (NOHA5). Thrombosis and Haemostasis 81 891-899.

Gris JC, Quere I, Sanmarco M, Boutiere B, Mercier E, Amiral J, Hubert AM, Ripart-Neveu S, Hoffet M, Tailland ML et al. 2000 Antiphospholipid and antiprotein syndromes in non-thrombotic, non-autoimmune women with unexplained recurrent primary early foetal loss. The Nimes Obstetricians and Haematologists Study-NOHA. Thrombosis and Haemostasis 84 228-236.

Gris JC, Perneger TV, Quere I, Mercier E, Fabbro-Peray $\mathbf{P}$, Lavigne-Lissalde G, Hoffet M, Dechaud H, Boyer JC, RipartNeveu S et al. 2003 Antiphospholipid/antiprotein antibodies, hemostasis-related autoantibodies, and plasma homocysteine as risk factors for a first early pregnancy loss: a matched case-control study. Blood 102 3504-3513.

Huang T, Owolabi T, Summers AM, Meier C \& Wyatt PR 2005 The identification of risk of spontaneous fetal loss through second-trimester maternal serum screening. American Journal of Obstetrics and Gynecology 193 395-403.

Lee RM, Emlen W, Scott JR, Branch DW \& Silver RM 1999 Antibeta2-glycoprotein I antibodies in women with recurrent spontaneous abortion, unexplained fetal death, and antiphospholipid syndrome. American Journal of Obstetrics and Gynecology 181 642-648.

Levine JS, Branch DW \& Rauch J 2002 The antiphospholipid syndrome. New England Journal of Medicine 346 752-763.

Lynch A, Byers T, Emlen W, Rynes D, Shetterly SM \& Hamman RF 1999 Association of antibodies to beta2-glycoprotein 1 with pregnancy loss and pregnancy-induced hypertension: a prospective study in low-risk pregnancy. Obstetrics and Gynecology 93 193-198.

Mahjoub T, Mtiraoui N, Tamim H, Hizem S, Finan RR, Nsiri B \& Almawi WY 2005 Association between adverse pregnancy outcomes and maternal factor V G1691A (Leiden) and prothrombin G20210A genotypes in women with a history of recurrent idiopathic miscarriages. American Journal of Hematology $\mathbf{8 0}$ $12-19$. 
Marai I, Tincani A, Balestrieri G \& Shoenfeld Y 2005 Anticardiolipin and anti-beta-2-glycoprotein I antibodies. Autoimmunity 38 33-38.

Martinelli I, Taioli E, Cetin I \& Mannucci PM 2002 Recurrent late fetal death in women with and without thrombophilia. Thrombosis and Haemostasis 87 358-359.

Matsubayashi H, Arai T, Izumi S, Sugi T, Mclntyre JA \& Makino T 2001 Anti-annexin V antibodies in patients with early pregnancy loss or implantation failures. Fertility and Sterility 76 694-699.

Mercanoglu F, Erdogan D, Oflaz H, Kucukkaya R, Selcukbiricik F, Gul A \& Inanc M 2004 Impaired brachial endothelial function in patients with primary anti-phospholipid syndrome. International Journal of Clinical Practice 58 1003-1007.

Miyakis S, Giannakopoulos B \& Krilis SA 2004 Beta 2 glycoprotein I-function in health and disease. Thrombosis Research 114 $335-346$

Mtiraoui N, Borgi L, Hizem S, Nsiri B, Finan RR, Gris J-C, Almawi WY \& Mahjoub T 2005 Prevalence of antiphospholipid antibodies, factor V G1691A (Leiden) and prothrombin G20210A mutations in early and late recurrent pregnancy loss. European Journal of Obstetrics, Gynecology, and Reproductive Biology 119 164-170.

Norwitz ER, Schust DJ \& Fisher SJ 2001 Implantation and the survival of early pregnancy. New England Journal of Medicine 345 1400-1408.

Quenby S, Farquharson RG, Dawood F, Hughes AM \& Topping J 2005 Recurrent miscarriage and long-term thrombosis risk: a casecontrol study. Human Reproduction 20 1729-1732.

Rand JH, Wu XX, Guller S, Gil J, Guha A, Scher J \& Lockwood CJ 1994 Reduction of annexin-V (placental anticoagulant protein-I) on placental villi of women with antiphospholipid antibodies and recurrent spontaneous abortion. American Journal of Obstetrics and Gynecology 171 1566-1572.
Rand J, Eerden PV, Wu XX \& Chazotte C 2005 Defective annexin A5 crystallization: a mechanism for pregnancy losses in the antiphospholipid syndrome. Thrombosis Research 115 (Suppl 1) 77-81.

Romisch J, Seiffge D, Reiner G, Paques EP \& Heimburger N 1991 In-vivo antithrombotic potency of placenta protein 4 (annexin V). Thrombosis Research 61 93-104.

Siaka C, Lambert M, Caron C, Amiral J, Hachulla E, Hatron PY \& Goudemand J 1999 Low prevalence of anti-annexin V antibodies in antiphospholipid syndrome with fetal loss. La Revue de medecine interne $20762-765$.

Tan NH, Yahya A \& Adeeb N 1995 Sociobiological risk factors for spontaneous abortion in Malaysia. Journal of Obstetrics and Gynaecology 21 313-318.

Van Ryn-McKenna J, Merk H, Muller TH, Buchanan MR \& Eisert WG 1993 The effects of heparin and annexin $V$ on fibrin accretion after injury in the jugular veins of rabbits. Thrombosis and Haemostasis $69227-230$

Wang X, Campos B, Kaetzel MA \& Dedman JR 1999 Annexin V is critical in the maintenance of murine placental integrity. American Journal of Obstetrics and Gynecology 180 1008-1016.

Wilcox AJ, Weinberg CR, O'Connor JF, Baird DD, Schlatterer JP, Canfield RE, Armstrong EG \& Nisula BC 1988 Incidence of early loss of pregnancy. New England Journal of Medicine 319 189-194.

Received 1 December 2005

First decision 11 January 2006

Revised manuscript received 15 January 2006

Accepted 17 January 2006 